\title{
Seasonal trends in milk quality in Ireland between 2007 and 2011
}

\author{
A. O’Connell, ${ }^{*}{ }^{1}$ S. McParland, ${ }^{*}$ P. L. Ruegg, $\dagger$ B. O’Brien, ${ }^{*}$ and D. Gleeson* \\ *Teagasc, Livestock Systems Research Department, Animal and Grassland Research and Innovation Centre, Moorepark, Fermoy, \\ Co. Cork, Ireland \\ †Department of Dairy Science, University of Wisconsin-Madison, Madison 53706
}

\begin{abstract}
The objectives of this study were to evaluate annual and seasonal trends in bulk tank somatic cell count (SCC), total bacterial count (TBC), and laboratory pasteurization count (LPC) in Ireland between 2007 and 2011 (inclusive), and to compare trends based on herd type and herd size. The unadjusted median SCC and TBC of all records were 266,000 and 17,000 $\mathrm{cfu} /$ $\mathrm{mL}$, respectively. Data were transformed to $\log$ values and analyzed using a mixed model. Fixed effects included milk processor, year, month, and total monthly milk volume; milk producer was fitted as a random variable. After analysis, means were back transformed for interpretation. Annual SCC increased slightly from 259,000 cells $/ \mathrm{mL}$ in 2007 to a peak of 272,647 cells/mL in 2009 and then declined slightly thereafter. Although statistically significant changes in annual TBC are probably not biologically relevant, values ranged between 23,922 and 26,290 cfu/mL. Annual LPC peaked in 2008 (265 cfu/mL), declined in 2009, and increased thereafter. Monthly mean SCC of all records increased from April onward, with the greatest increases seen from October to December, when the majority of cows entered late lactation. Monthly mean TBC exhibited a seasonal trend, whereby TBC was greatest at the beginning and end of the year, coinciding with winter housing. Seasonal milk production herds $(\mathrm{n}=8,002$ herds) calve all cows in spring (February to April), whereas split-calving herds ( $\mathrm{n}=1,829$ herds) calve cows in the spring and autumn. From February to September, monthly SCC was lower for seasonal herds than for split-calving herds, whereas SCC was lower for splitcalving herds for the remaining months. During winter (October to March), split-calving herds had lower monthly TBC than seasonal herds, most likely because of stricter regulations imposed upon them. Herd size was approximated using total annual milk production figures. Across all months, larger herds had lower SCC and TBC compared with smaller herds. No obvious im-
\end{abstract}

Received October 21, 2014.

Accepted February 11, 2015.

${ }^{1}$ Corresponding author: aine.oconnell@teagasc.ie provements in milk quality were seen between 2007 and 2011. Farmers have the opportunity to improve milk quality by reducing bulk tank SCC in late lactation and by imposing stricter hygiene practices at the beginning and end of the year to overcome the seasonal variation of bulk tank TBC.

Key words: milk quality, herd size, somatic cell count, trend, total bacteria count

\section{INTRODUCTION}

Due to increasing market demand, forthcoming Common Agricultural Policy reform, and abolition of the milk quota system, milk production in Ireland is expected to dramatically increase (DAFM, 2010a). Improvements in udder health and milk quality are needed to maximize the ability of Irish dairy products to compete in export markets (More, 2009). In Ireland, the quality of raw bulk milk is routinely measured using total bacteria count (TBC) and SCC. In addition, some processors routinely use laboratory pasteurization count (LPC) to measure the quantity of thermoduric bacteria.

Bulk tank milk SCC is a general indicator of the overall udder health status of a herd (van Schaik et al., 2002; Schukken et al., 2003). Somatic cells are part of the innate immune system of the cow and are almost always a reflection of the inflammatory response to an IMI (Schukken et al., 2003). Bulk tank milk from herds with increased SCC has an increased risk of containing antibiotic residues (Ruegg and Tabone, 2000) and is one indicator of animal welfare (van Schaik et al., 2002; Schukken et al., 2003; Bertocchi et al., 2012). Both flavor and shelf life of pasteurized dairy products are altered when high-SCC milk is used (Barbano et al., 2006), and cows with subclinical mastitis produce less milk (Halasa et al., 2009). For an average Irish dairy herd, annual net herd losses from subclinical mastitis are estimated to reach $€ 19,504$ as bulk tank SCC increases from $<100,000$ to $>400,000$ cells $/ \mathrm{mL}$ (Geary et al., 2012).

The TBC of bulk tank milk is an estimate of the quantity of aerobic bacteria (Chambers, 2002). The TBC is commonly used for regulatory purposes and fre- 
quently by milk processors to help determine the milk price received by producers (Hayes et al., 2001). Bulk tank TBC is a comprehensive reflection of the hygienic conditions of the herd and can be influenced by teat preparation, prevalence of IMI in the herd, sanitation of milking equipment, and milk storage temperature (Hayes et al., 2001; Chambers, 2002; Ruegg and Reinemann, 2002).

The LPC is used to quantify thermoduric bacteria in milk and is often used as an indicator of milking equipment sanitation. A high LPC can indicate chronic cleaning failure (Jayarao and Wolfgang, 2003; Pantoja et al., 2009). An LPC $<200 \mathrm{cfu} / \mathrm{mL}$ is considered normal, whereas $\mathrm{LPC}<10 \mathrm{cfu} / \mathrm{mL}$ indicates excellent equipment hygiene (Ruegg and Reinemann, 2002).

The European Union (EU) imposes a regulatory limit on bulk tank milk of $<400,000$ SCC cells/ $\mathrm{mL}$ (geometric average over a period of $3 \mathrm{mo}$, with at least 1 sample a month) and $<100,000$ TBC cfu/ $\mathrm{mL}$ (geometric average over a period of $2 \mathrm{mo}$, with at least 2 samples a month; EEC, 1992, Council Directive 92/46/EEC). When regulatory standards for bacterial counts are met, pasteurization of raw milk is highly effective in destroying foodborne pathogens (Ruegg, 2003). Currently, the EU does not specify a regulatory threshold for LPC but some processors have adopted a penalty when values exceed 1,000 cfu/mL. Some Irish milk processors have financial incentives for farmers to produce milk with bulk tank SCC $<200,000$ cells/ $\mathrm{mL}, \mathrm{TBC}<30,000 \mathrm{cfu} / \mathrm{mL}$, and $\mathrm{LPC}<500 \mathrm{cfu} / \mathrm{mL}$. Previous analyses of bulk tank milk quality trends in Ireland (Berry et al., 2006) have shown that farmers are unable to maintain SCC of bulk milk $<250,000$ cells/ $\mathrm{mL}$, particularly toward the end of seasonal lactation periods (November to December).

Most Irish dairy herds rely on grass as the primary nutrient source for their cattle (Dillon et al., 1995). Milk production in Ireland is predominantly based on seasonal calving, whereby farmers calve all their cows in spring (February to April) to coordinate peak milk production with periods of peak grass growth. However, to maintain the fresh milk supply, a small proportion of cows are calved in the autumn. Herds that calve cows in both spring and autumn are referred to as split-calving herds. Differences in milk quality between seasonal and split-calving herds have not been previously described.

Average herd size in Ireland tripled between 1985 and 2010 (Dillon, 2011) and is expected to continue to increase. The average herd size in Ireland is 58 cows, and $11.25 \%$ of farmers have herds with more than 100 cows (Central Statistics Office; CSO, 2012). Facilities and management practices often differ based on herd size and have been associated with differences in bulk milk SCC. A Wisconsin study demonstrated that smaller dairy herds had significantly greater SCC and TBC compared with larger herds (Rodrigues et al., 2005). However, for Irish dairy herds, inconsistent associations of herd size with milk quality have been reported (Berry et al., 2006; Archer et al., 2013).

The objectives of this study were to assess trends in bulk tank SCC, TBC, and LPC in Irish dairy herds between 2007 and 2011 and to compare trends based on milk herd type and herd size.

\section{MATERIALS AND METHODS}

\section{Data}

The complete data set (combined data set) was supplied by 9 milk processors in Ireland and consisted of bulk tank SCC and TBC obtained from January 2007 through December 2011. Depending on processor, SCC was evaluated using Fossomatic (Foss Electric, Hillerød, Denmark) or Somacount (Bentley Instruments, Chaska, MN) instruments. Different procedures to measure TBC were used among processors and included the Thompson plate loop method (Thompson et al., 1960), Petrifoss SPC (Foss Electric), and the Bactoscan machine (Foss Electric). The Bactoscan IBC (individual bacteria count) values were converted to colony-forming unit values by the processors before supplying the data. The Department of Agriculture is responsible for ensuring that all conversions are the same across milk processors (DAFM, 2011). Frequency of SCC and TBC testing per month differed depending on processor and ranged between 4 and 10 times for SCC and between 2 and 4 times for TBC. Data for LPC were provided by one processor from 2007 to 2011 inclusive, and were evaluated using the Petrifoss SPC (Foss Electric) with a minimum detection limit of $10 \mathrm{cfu} / \mathrm{mL}$.

Five milk processors provided monthly data for each of their herds that included total monthly milk volume and monthly mean values for SCC and TBC. The remaining 4 processors provided daily milk collection data for each herd that included the date of milk collection, milk volume, SCC, and TBC. For data obtained from these processors, daily milk volume was summed for each month, and monthly averages were calculated for TBC and SCC for each herd.

Values for SCC that were $<20,000$ cells $/ \mathrm{mL}$ were removed. Any TBC values that were $<1,500 \mathrm{cfu} / \mathrm{mL}$ or $>10$ million $\mathrm{cfu} / \mathrm{mL}$ (values outside of the operating range of the Bactoscan) were also removed. Records with monthly milk volume $<227.5 \mathrm{~L}$ (the minimum milk volume collected by milk processors in Ireland) were also removed. Herds that supplied milk for less 
than $6 \mathrm{mo} / \mathrm{yr}$ or were not included in all years of the study were also excluded. The distributions of monthly arithmetic means for SCC, TBC, and LPC values were positively skewed and so, to improve the normality of the distributions, the monthly means were transformed to base 10 logs.

\section{Comparison of Herd Types}

To compare data between herd types, herds were categorized as seasonal or split calving based on their annual calving patterns. Seasonal herds calved all cows between February and April and were defined as herds in which peak milk production occurred in May or June and exceeded the herd's minimum monthly milk production in the herd-year by $>700 \%$. To achieve yearround fresh milk supply, split-calving herds milk 2 calving cohorts. The spring cohort is calved from February to April and the winter cohort is calved from August onward. Split-calving herds were defined as herds that supplied milk throughout December and January and had peak milk production that exceeded herd minimum milk production for any month by $<300 \%$. Herds could be identified as seasonal or split calving for one or more years. Herds that did not meet the criteria for either seasonal or split calving for any year and herds that met both seasonal and split-calving criteria across different years were excluded.

\section{Herd Size}

Cow numbers per herd were not available; therefore, herd-size quartiles were estimated based on total annual milk volume. Milk yield was assumed to be 4,562 $\mathrm{kg} /$ cow per year (ICAR, 2009). Threshold values used to categorize herds into size quartiles were $<162,881$ $\mathrm{L} / \mathrm{yr}$ (herd size $1,<36$ cows), 162,881 to $252,735 \mathrm{~L} /$ yr (herd size $2,36-55$ cows), 252,736 to $366,764 \mathrm{~L} / \mathrm{yr}$ (herd size 3, 56-80 cows), and >366,764 L/yr (herd size $4,>80$ cows).

\section{Statistical Analysis}

Monthly and annual least squares means for each response variable were calculated using the HPMIXED procedure in SAS 9.3 (SAS Institute, 2011). Response variables were $\log _{10}$ SCC, $\log _{10}$ TBC, and $\log _{10} \mathrm{LPC}$. The fixed effects of processor (1 to 9), year (2007 to 2011), month (January to December) and monthly volume on monthly and annual mean SCC and TBC were assessed in 2 separate models using the combined data set. Fixed effects of year, month, and milk volume on annual and monthly LPC were analyzed using data supplied by one processor. Milk producer was included as a random effect in all models.

The combined data set was also used to analyze the effect of herd size on monthly SCC and TBC. Fixed effects included in the models included processor, year and month and the interaction between herd size and month. Milk producer was included as a random effect.

The general mixed model used in all analyses was as follows (volume was not included when assessing the effect of herd size on monthly SCC and TBC):

$$
\mathrm{Y}=\mu+\mathrm{PR}+\mathrm{YR}+\mathrm{MO}+\mathrm{VOL}+\text { Producer }+\mathrm{e},
$$

where $\mathrm{y}=\log _{10} \mathrm{SCC}, \log _{10} \mathrm{TBC}$, or $\log _{10} \mathrm{LPC}$; PR $=$ fixed effect of each individual processor; $\mathrm{YR}=$ fixed effect of year; $\mathrm{MO}=$ fixed effect of month; $\mathrm{VOL}=$ fixed effect of the volume of milk supplied each month; Producer $=$ random effect of milk producer; and $\mathrm{e}=$ residual component.

Herds identified as either seasonal or split calving from the combined data set were used to investigate the effect of herd type on monthly SCC and TBC. Fixed effects were processor, year, month, and milk volume; milk producer was included as a random effect; and the interaction between herd type and month was included in these models.

\section{RESULTS}

After editing, the combined data set included 589,207 $\log _{10}$ SCC, 527,616 $\log _{10}$ TBC, and 200,883 $\log _{10}$ LPC across 54,095 herd-years, representing 10,819 herds. A total of $63,658,58,222$, and 13,235 records of $\log _{10}$ SCC, $\log _{10}$ TBC, and $\log _{10} \mathrm{LPC}$, respectively, were excluded. Almost $10 \%$ of the original records were removed (Table 1). Deletions due to minimal milk volume and outliers were minimal (Table 1). Only 46 records had a monthly mean SCC $<20,000$ cells $/ \mathrm{mL}$, of which 30 records had an SCC value of 0 cells $/ \mathrm{mL}$ and the remaining 16 values had a value between 9,000 and 19,000 cells/mL.

Most records were excluded because herds did not supply milk for at least 6 mo per year or the herd was not present in all years (Table 1). In total, 3,878 herds were removed from the data set, of which 3,114 herds were removed for inconsistent supply. The number of milk producers that did not supply milk for all years of the study was 1,409 , whereas the number of milk producers that did not supply for at least 6 mo in each year was 1,705 . Of those 1,705 milk producers, only 363 milk producers supplied milk for all 5 yr. Of those 3,114 milk producers that were removed for inconsistent supply, 1,767 milk producers that supplied milk in 2007 did 
not supply milk in 2011 and it is assumed that they left dairying. The remaining 1,347 either entered dairying or supplied milk inconsistently between 2007 and 2011 . Trends for SCC and TBC for the removed herds were identical but annual and monthly means were between 50,000 and 100,000 cells/mL greater for SCC and between 2,500 and $7,000 \mathrm{cfu} / \mathrm{mL}$ greater for TBC than the herds included in this analysis (data not shown).

Of the remaining 10,819 herds, 8,002 and 1,829 were categorized as seasonal and split-calving herds, respectively. A total of 988 herds did not meet the criteria for seasonal or split for any year, whereas 895, 1,221, 1,710, 2,887 , and 4,106 herds were categorized as seasonal or split for 1, 2, 3, 4, and all years, respectively.

\section{Milk Supply}

During the study, milk production in the combined data set declined from 3.02 billion liters in 2007 to 2.96 billion liters in 2009 and then increased to 3.32 billion liters in 2011 (data not shown). As defined, seasonal herds had a distinct peak of milk supply during the summer months (May, June, and July), whereas splitcalving herds had a steadier supply of milk across the year and a less-pronounced peak during summer months.

\section{SCC}

For the combined data set, the overall unadjusted mean and median SCC were 298,415 and 266,000 cells/ $\mathrm{mL}$, respectively. Of all monthly average SCC in the combined data set, $25 \%$ were $<192,000$ cells $/ \mathrm{mL}$ and $10 \%$ were $>486,000$ cells $/ \mathrm{mL}$ (Table 2 ). Similar distributions of SCC for the seasonal and split-calving herds were observed. Although the split-calving data set had a slightly greater median SCC, the range between the minimum and 90th percentile $(399,000$ cells $/ \mathrm{mL})$ was less than that in the seasonal data set $(463,000$ cells/ $\mathrm{mL}$ ).

For the combined data set, small differences $(P<$ $0.01)$ in annual SCC were identified for all adjacent years. Annual mean SCC increased from 2007 (259,000 cells/mL), peaked in 2009 (272,647 cells/mL), and then declined to 244,399 cells $/ \mathrm{mL}$ in $2011(P<0.01$; data not shown).

Except for the months of April and May and November and December, monthly mean SCC for adjacent months were different $(P<0.01)$. Monthly SCC declined from January $(273,779$ cells/mL) until April (226,777 cells $/ \mathrm{mL})$ and then gradually increased for the remainder of the year (Figure 1). Peak SCC occurred in December (331,436 cells $/ \mathrm{mL})$. The greatest monthly 


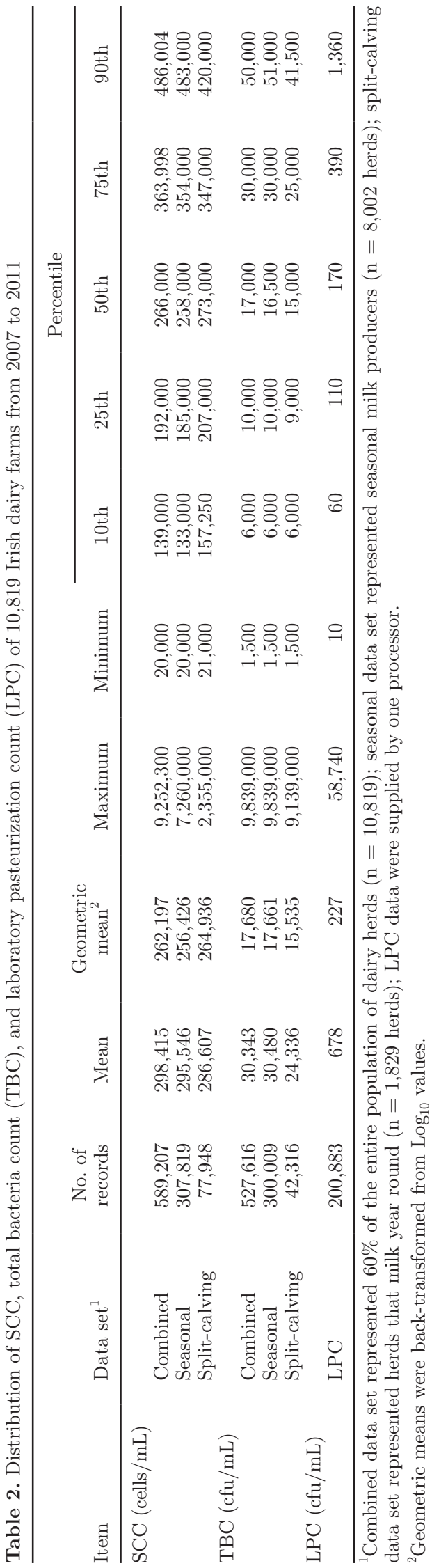

increase in SCC occurred between October $(279,254$ cells/mL) and November (330,522 cells/mL).

\section{Comparison of SCC Between Herd Types}

Except for January, monthly mean SCC were different $(P<0.01)$ between herds characterized as seasonal and split calving. From February until September, monthly SCC were greater for split-calving herds compared with seasonal herds. Monthly SCC were greater for seasonal herds for the remaining months (Figure $2 \mathrm{~A})$. Mean monthly SCC of seasonal herds peaked in December $(402,346$ cells $/ \mathrm{mL})$, whereas monthly SCC of split-calving herds peaked in August (307,893 cells/ $\mathrm{mL}$ ). The lowest monthly mean SCC was seen in April $(219,533$ cells $/ \mathrm{mL})$ for seasonal herds and in November (271,393 cells $/ \mathrm{mL})$ for split-calving herds.

\section{TBC}

The unadjusted mean and median TBC for the combined data set were 30,343 and $17,000 \mathrm{cfu} / \mathrm{mL}$, respectively (Table 2). The 25 th and 75 th percentiles were 10,000 and $30,000 \mathrm{cfu} / \mathrm{mL}$, respectively (Table 2). The distribution of TBC for the seasonal and split-calving herds was similar; however, the 90th percentile was almost 10,000 cfu/mL less for split-calving herds than for seasonal herds (Table 2).

For the combined data set, with the exception of 2008 and 2009, annual values for TBC were slightly different for all adjacent years $(P<0.01)$. Mean annual TBC were 24,837 and 25,817 cfu/mL for 2007 and 2011, respectively. Very small changes in TBC were observed across the study period (data not shown).

A seasonal trend was observed for monthly TBC. Except for the months of April and May and November and December, monthly TBC values for adjacent months were different $(P<0.01)$. Monthly means for the combined data set decreased from $36,325 \mathrm{cfu} / \mathrm{mL}$ (January) to $18,910 \mathrm{cfu} / \mathrm{mL}$ (May) and then increased to $35,686 \mathrm{cfu} / \mathrm{mL}$ in December (Figure 1).

Comparison of TBC Between Herd Types. Except in September, monthly mean TBC were different $(P<0.05)$ between herds characterized as seasonal or split calving. From January to March and from October to December, monthly TBC were greater for seasonal herds compared with split-calving herds. Monthly TBC were greater for split-calving herds for the remaining months (Figure 2B). Mean monthly TBC of seasonal herds peaked in January $(35,156 \mathrm{cfu} / \mathrm{mL})$, as did monthly TBC of split-calving herds $(23,735 \mathrm{cfu} / \mathrm{mL})$. The lowest monthly mean TBC was seen in May for seasonal herds $(15,399 \mathrm{cfu} / \mathrm{mL})$ and split-calving herds $(16,099 \mathrm{cfu} / \mathrm{mL})$. 


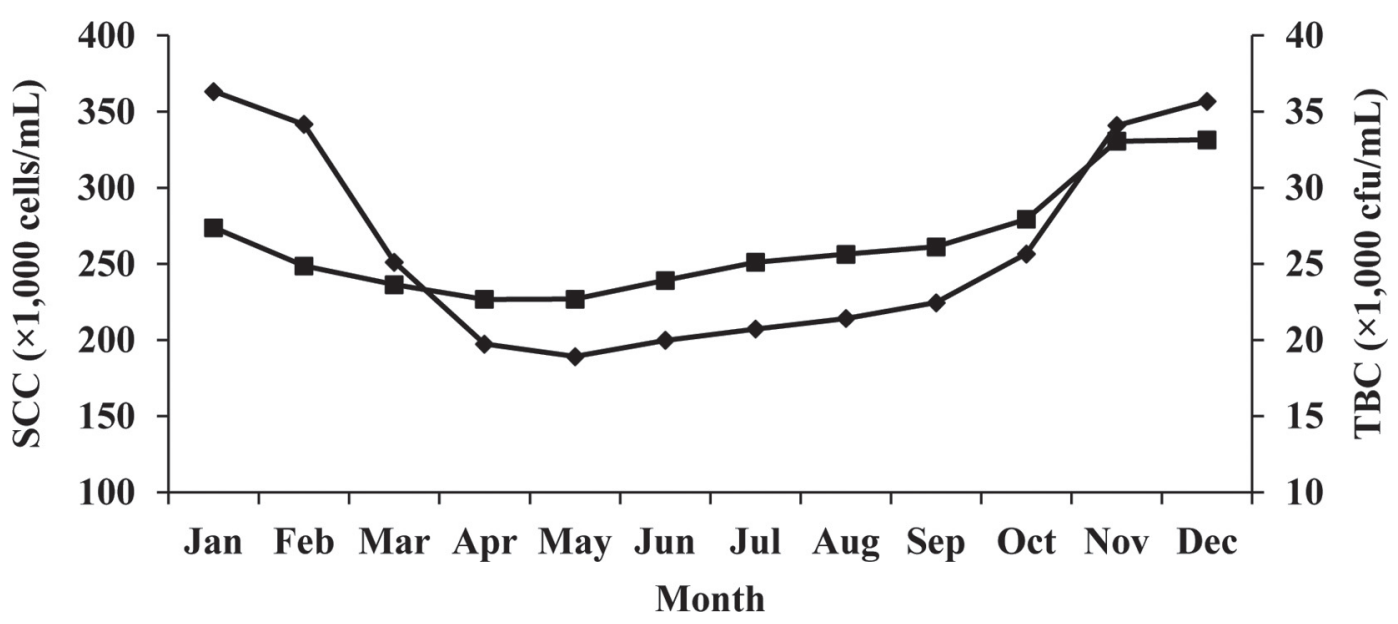

Figure 1. Monthly adjusted $\log _{10}$ means (back-transformed from $\log _{10}$ values after analysis) for SCC ( $\mathbf{\square}$ ) and total bacteria count (TBC; for the combined data set (10,819 Irish dairy herds, $60 \%$ of the entire population of dairy herds in Ireland) from 2007 to 2011.

Comparison of Monthly TBC and SCC Among Herd Sizes. Across all months, herds that sold the least amount of milk (herd size 1) had the greatest TBC and SCC (data not shown). Across all months, differences in SCC were observed between herd sizes 1 ( $<36$ cows) and 2 (36-56 cows), whereas differences in $\mathrm{TBC}$ were observed in all months except January and December. Differences in TBC between herd sizes 2 and 3 were observed across all months except January. Differences in TBC between herd sizes 3 and 4 were observed across all months except April to July and December. No significant differences in SCC were observed among herd sizes 2, 3, and 4 during February. Differences in SCC between herd sizes 3 and 4 were observed across all months except during the summer months of June, July, and August (Figure 3).

\section{LPC}

For LPC, all adjacent years were different $(P<0.01$; data not shown): LPC increased from $194 \mathrm{cfu} / \mathrm{mL}$ in 2007 to $265 \mathrm{cfu} / \mathrm{mL}$ in 2008 , declined to $216 \mathrm{cfu} / \mathrm{mL}$ in 2009, and then increased to $263 \mathrm{cfu} / \mathrm{mL}$ in 2011. Month by year interactions showed that LPC were greater between June and August 2008 compared with other years. The LPC for June, July, and August 2008 were 283,348 , and $374 \mathrm{cfu} / \mathrm{mL}$, respectively. Meanwhile, LPC for these months in remaining years ranged between 145 and $282 \mathrm{cfu} / \mathrm{mL}$.

Values for LPC demonstrated seasonal trends. The LPC was least in March and April, increased until September and October, and then declined (Figure 4). Differences in LPC were observed for the months of February and March, all months between May and August, and between October and November $(P<0.01)$.

\section{DISCUSSION}

The sustained delivery of high-quality dairy products depends on production of raw bulk milk with minimal bacterial contamination and SCC (Elmoslemany et al., 2010; Ruegg and Pantoja, 2013). Monitoring of trends in milk quality allows industry stakeholders to assess progress, evaluate the efficiency of control programs, and identify critical management issues. Knowledge of regional trends in milk quality can provide insight into how external factors (such as climate, milk pricing, and production systems) influence milk quality and increase understanding about differences in milk quality throughout the world.

The data included in this study were a convenience sample obtained from 9 processors. Herds were not randomly sampled and the results may not be representative of the entire Irish dairy industry. However, participating processors collected milk from $60 \%$ of all dairy herds in Ireland (IDF, 2012) and results can likely be extrapolated to most dairy herds in the regions where the processors operate. Additionally, the increase in milk yield of $9.44 \%$ seen in this study and the estimated herd size of 65 cows reflect national figures that indicate an increase in milk production of $10 \%$ and estimate current herd size to be 58 cows (CSO, 2012, 2014). It is also realistic to assume that the results may be applicable to dairy herds in other regions that have a similar climate and use similar production systems.

In the current study, annual bulk tank SCC reached a peak of 272,647 cells/mL in 2009 (an increase of almost 9,000 cells $/ \mathrm{mL}$ from the previous year). Although statistically significant, this increase is probably not biologically relevant. During the same period, other EU countries (such as Spain and Belgium) reported similar 

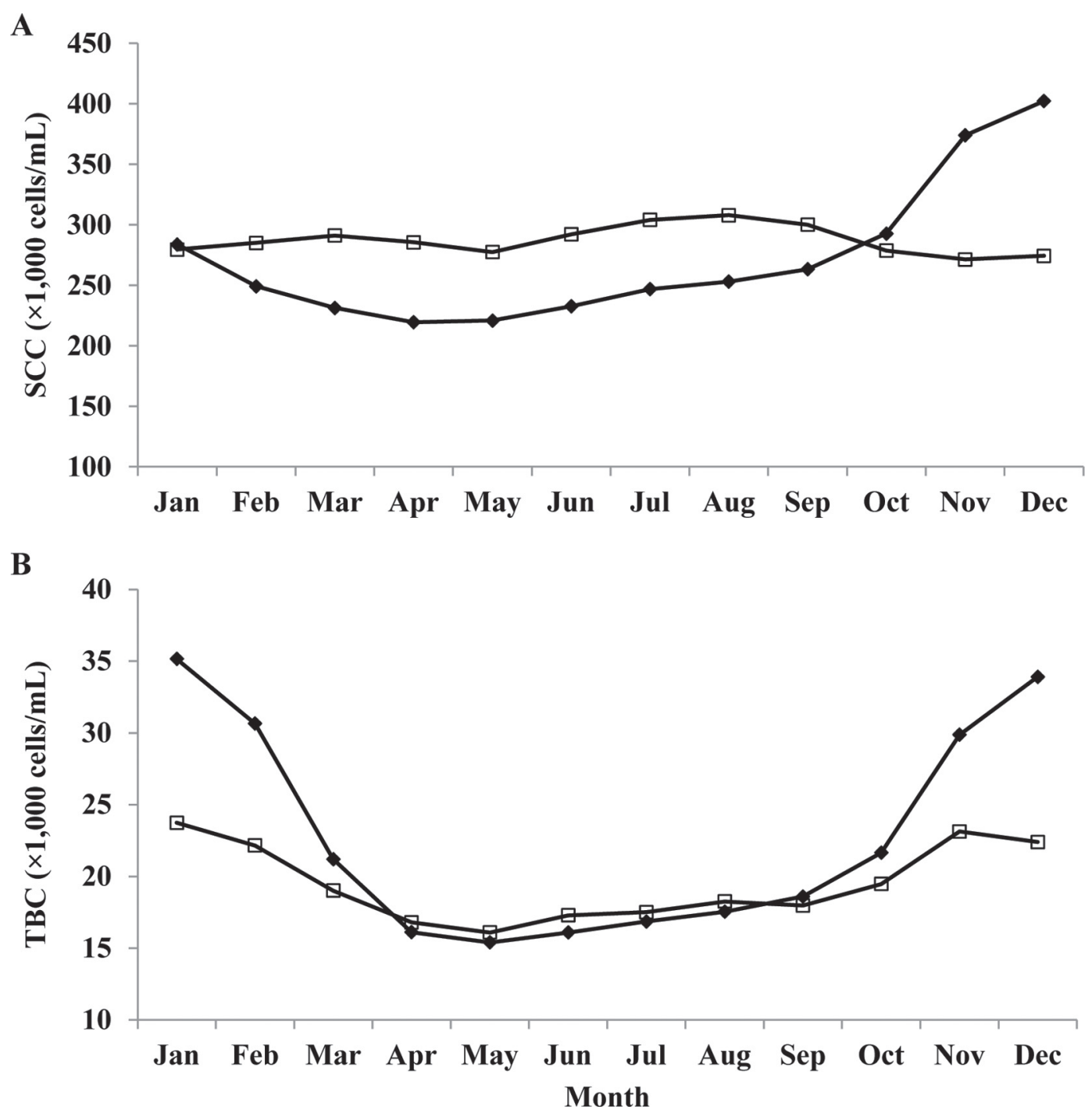

Figure 2. Comparison of monthly SCC (A) and total bacteria count (TBC; B) means (back-transformed from $\log _{10}$ values after analysis) for seasonal [ ; seasonal milk producers $(\mathrm{n}=8,002$ herds) in Ireland] and split-calving $[\square$; producers that milk year round $(\mathrm{n}=1,829$ herds) in Ireland] data sets from 2007 to 2011.

minimal increases in SCC (De Vliegher; 2013; Jimenez, 2013). The worldwide decrease in milk prices in 2009 (IFCN, 2009) may have resulted in less investment in control practices and increased incidence of IMI.

To effectively manage bulk tank SCC, it is necessary to identify cows and quarters with high SCC. Participation in milk recording schemes has been associated with lower bulk tank SCC in Ireland (Kelly et al., 2009a). Although milk recording identifies problem cows, it is the subsequent actions of the farmer that have the ability to result in lower bulk SCC. Such actions include culture, segregation, treatment, or removal of infected cows from the herd (Cook et al., 2002; Rhoda and Pantoja 2012). The number of cows enrolled in a milk-recording scheme in Ireland declined by $8 \%$ from 2008 to 2009 , likely as a consequence of the severe financial pressure due to the decrease in milk price (ICBF, 2009). Subsequently, the number of cows enrolled increased by 10\% from 2009 to 2011 (ICBF, 2011) while SCC declined by 28,248 cells $/ \mathrm{mL}$. Likewise, enrollment in milk-recording programs in the United States has been associated with reduced prevalence of subclinical mastitis (Wilson et al., 1997). United States dairy herds enrolled in monthly DHI testing of SCC have demonstrated continuous annual reductions in test-day SCC from 276,000 cells/mL (2007) to 217,000 cells/mL (2011; NMC, 2012). The substantial decrease in milk price experienced by farmers in 2009 in Ireland 


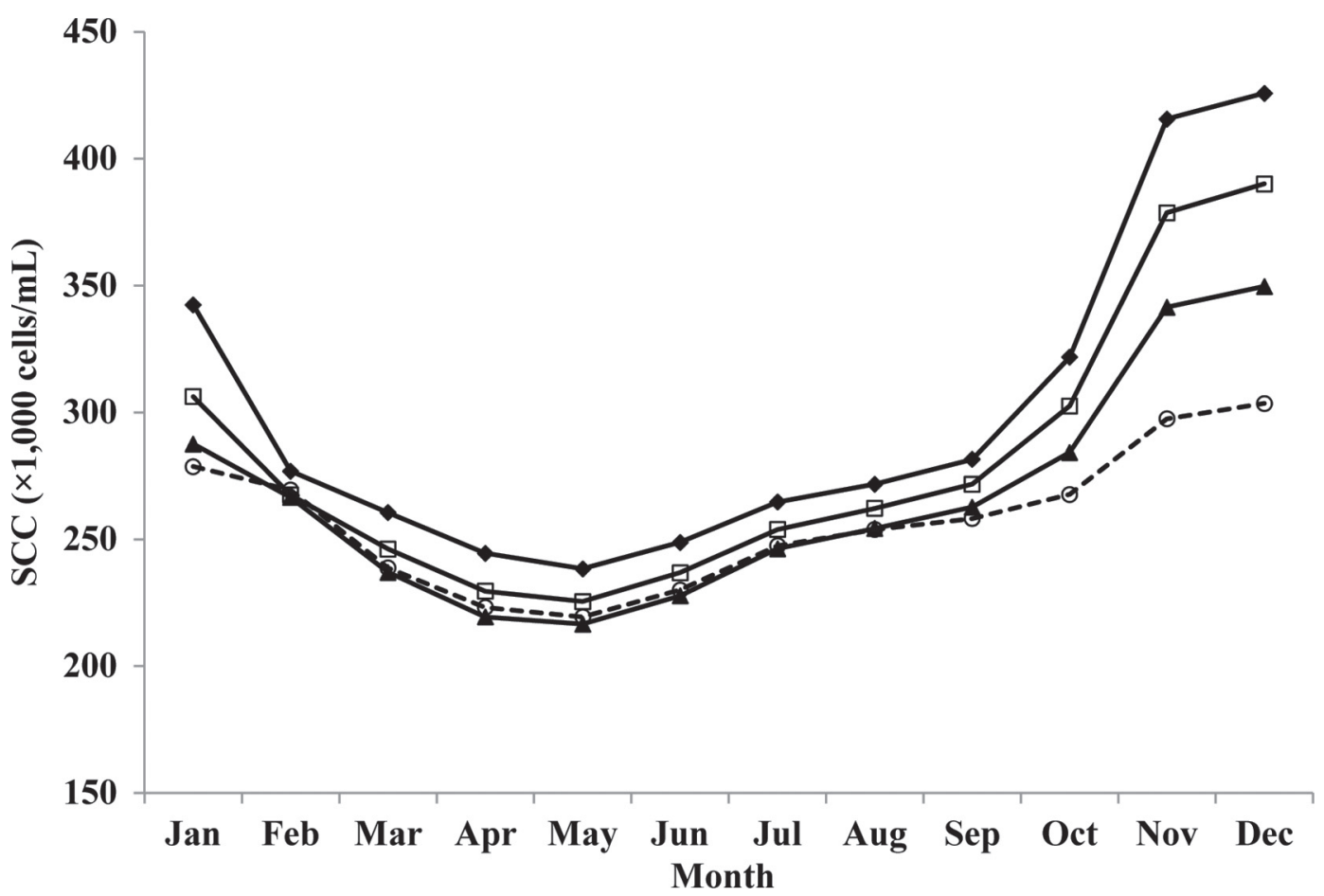

Figure 3. Association between herd size and SCC of Irish dairy herds. Herd size $1(\bullet)=<162,881 \mathrm{~L} /$ yr, $<36$ cows; herd size 2 ( $\square$ ) $=162,881$ to $252,735 \mathrm{~L} / \mathrm{yr}$, between 36 and 56 cows; herd size $3(\boldsymbol{\Delta})=252,736$ to $366,764 \mathrm{~L} / \mathrm{yr}$, between 56 and 81 cows; herd size 4 (-O-, dashed line) = $>366,764 \mathrm{~L} / \mathrm{yr},>81$ cows. Monthly means were back-transformed from $\log _{10}$ values after analysis.

(DAFM, 2010b) may have resulted in less investment by farmers in mastitis control and milk recording for that year.

Cell Check is an Irish program that was established by Animal Health Ireland in 2009 with the objective of providing guidance and resources to help farmers produce higher quality milk (http://www.animalhealth ireland.ie). Bulk tank SCC values can respond rapidly to interventions (Rodrigues et al., 2005), and the launching of the Cell Check program may have influenced some dairy producers to work proactively to prevent mastitis. Additional factors that may have resulted

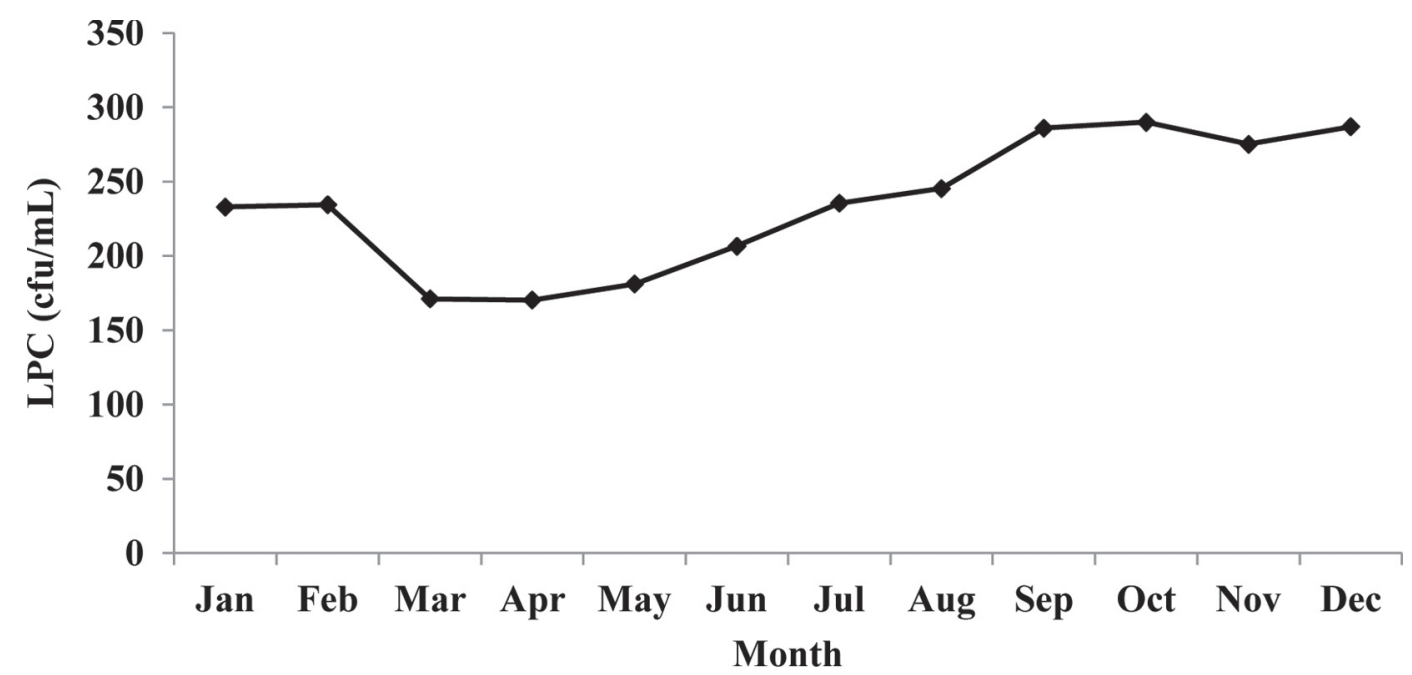

Figure 4. Monthly adjusted $\log _{10}$ means (back-transformed from $\log _{10}$ values after analysis) for laboratory pasteurization count (LPC; data are from one Irish processor only) from 2007 to 2011. 
in lower BTSCC since 2009 include an increased milk price (National Milk Agency, 2010) and considerably less rainfall in 2010 (Met Éireann, 2010).

Due to the dominance of seasonal milk production in Ireland, any seasonal effects seen in monthly means for the combined data set are highly confounded with DIM. Therefore, it is difficult to establish seasonal trends independent of DIM. For herds included in the combined data set, monthly mean SCC was least during spring (February to April) and increased from May, with the greatest increase occurring between October and December. Similar but less-pronounced trends have been reported for dairy herds in New Zealand (DairyNZ, 2011). It is well documented that bulk milk SCC increases toward the end of lactation (Berry et al., 2006; Hagnestam-Nielsen et al., 2009; Kelly et al., 2009a) and is related to increased prevalence of cows with chronic subclinical mastitis. Herds with greater bulk tank SCC ( $>200,000$ cells $/ \mathrm{mL}$ ) tend to have greater prevalence of IMI caused by contagious pathogens (Fenlon et al., 1995; Barkema et al., 1998; Rodrigues et al., 2005).

For the combined data set, peak milk production coincided with the lowest monthly mean bulk tank SCC. At the herd level, dilution due to increased milk production can contribute to a reduction in bulk tank SCC (Schepers et al., 1997). However infection at the cow level can still exist. When corrected for stage of lactation and test-day milk yield, individual cow SCC was greater and more variable in spring and summer compared with autumn and winter (Archer et al., 2013). This result highlights the importance of identifying and managing infected cows during spring and summer to prevent chronic infections from persisting into late lactation. The most prevalent mastitis pathogens among Irish herds are Staphylococcus aureus and Streptococcus uberis (Barrett et al., 2005; Keane et al., 2013). The prevalence of Staph. aureus mastitis in dairy herds is likely to increase with DIM due to increased exposure. Reducing bulk tank SCC in late lactation requires preventative action such as the implementation of the 5-point plan (Neave et al., 1969) and segregation of chronically infected cows earlier in lactation or premature dry-off of high-SCC cows.

Previous research conducted in the Netherlands has shown that farmers are more likely to respond to penalties (rather than bonuses) regarding the adoption of management measures aimed at improving udder health (Huijps et al., 2010). In Ireland, the SCC threshold for penalty was set at 400,000 cells/mL during 2007 and 2011. Monetary penalties applied to farmers by the processors are based on monthly arithmetic SCC means. In the current study, monthly mean SCC only approached threshold limits for penalty in November and December. For the majority of Irish dairy produc- ers (seasonal farmers), these months coincide with the end of lactation and drying off. As most farmers can maintain SCC below the penalty threshold for most of the lactation, there is little incentive for farmers to improve SCC in late lactation when minimal milk is produced. Additionally, although the EU limit for SCC is 400,000 cells $/ \mathrm{mL}$, this figure is based on a 3-mo rolling geometric mean. Thus, for seasonal herds, the dry months will compensate for the high SCC experienced at the end of lactation so it is very unlikely that milk collection will be refused despite considerably greater bulk tank SCC. Therefore, farmers can meet EU regulations without need for management changes that result in lower SCC.

To identify seasonal and split-calving herds from the national data set, we used the proportion of milk volume sold each month and the months in which milk was supplied. Peak milk production on seasonal herds typically occurs in May or June (90 d after calving). Thus, to be classified as a seasonal farm, peak milk production had to occur in May or June. Typically, seasonal farms will not milk during December and January (the dry period for spring-calving cows); therefore, to define split-calving herds, milk supply during these typical dry months was necessary. The national milk supply peak-to-trough ratio is 5.1:1 in Ireland (CSO, 2011), indicating the dominance of seasonal milk production in Ireland. Split-calving farms should have a lower ratio than this because they supply milk year round; thus, a benchmark of 3:1 was put in place to identify these herds. Alternatively, a ratio of 7:1 was put in place to identify seasonal herds.

Seasonal herds had lower monthly mean SCC from February to August and a greater SCC from October to January compared with split-calving herds. These trends correspond roughly to differences in stage of lactation resulting from differing calving periods. Between February and August, average DIM is greater for cows in split-calving herds because cows in the winter-calving cohort are in late lactation and all cows in seasonal herds are in early or mid lactation. In contrast, between October and January, average DIM for cows in seasonal herds is greater because all cows are in late lactation, whereas cows in the winter-calving cohort in split-calving herds are in early lactation. When contagious mastitis is present in a herd, the prevalence of cows with increased SCC usually increases with DIM as a result of persistent chronic IMI and increased risk of new IMI (Ruegg and Pantoja, 2013).

The pathogen profile of subclinical mastitis of 15 herds in Ireland indicated that Strep. uberis mastitis was more frequently isolated from high-SCC cows in split-calving herds than in seasonal herds, whereas Staph. aureus was more frequently isolated from high- 
SCC cows in seasonal herds (Barrett et al., 2005). Both pathogens can behave in a contagious manner (Zadoks et al., 2003; Barkema et al., 2006) and spread from infected quarters to healthy quarters at milking time. Minimizing the spread of contagious pathogens must be a goal for both seasonal and split-calving herds.

Although statistically significant, changes in bulk tank TBC throughout the study were minimal and probably not biologically relevant. Monthly arithmetic means for TBC were received from the processors and log-transformed to improve the normality of the distribution. Though this transformation dramatically improved the distribution, the data were still slightly skewed, likely because monthly arithmetic means were used, which are greatly influenced by extreme values. Therefore, caution is warranted when comparing these values to those of other studies.

Annual means of TBC have remained unchanged in the United Kingdom for the same period (DairyCo, 2014). Berry et al. (2006) reported that bulk tank TBC of Irish dairy farms $(\mathrm{n}=9,113)$ decreased from approximately $30,000 \mathrm{cfu} / \mathrm{mL}$ (1994) to $16,000 \mathrm{cfu} / \mathrm{mL}$ (2004). The 1992 imposition of EU policies for milking sanitation was considered to be the main cause of the reduction. Continued declines in TBC were not observed in the current study. Since 1992, no new policies for TBC have been implemented and so farmers may have become complacent about maintaining low TBC. As a result, bulk tank TBC of herds in the combined data set were considerably greater than that reported in 2004. Annual means of TBC easily meet EU thresholds and processors do not provide financial incentives that encourage further improvements in bulk tank TBC.

Most milk produced on Irish dairy herds is stored for a minimum of $48 \mathrm{~h}$ and may be stored for up to 4 $\mathrm{d}$ during the beginning and end of seasonal lactation periods, allowing considerable time for growth of bacteria (Champagne et al., 1994). The unadjusted mean TBC for 16 large Wisconsin herds was $12,545 \mathrm{cfu} / \mathrm{mL}$ (Pantoja et al., 2009), and the majority of the herds (average herd size of 924 cows) shipped milk directly to the plant at least once per day. Compared with Wisconsin herds, the longer storage of milk in farm bulk tanks may have allowed for incubation and resulted in greater TBC for the Irish farms participating in the current study. The effect of storage time on bacterial growth is very much dependent on the initial count at milk harvest. Although some processors provided data regarding pick-up frequency, examining the effect of pick-up frequency on TBC alone would neglect other factors such as hygiene and the initial quality of milk, which are likely to be more influential on the bacteria count. Risk factors for greater TBC on Irish herds include dirty housing conditions, absence of hot water washing, and absence of teat preparation (Kelly et al., $2009 b)$. Fewer than $10 \%$ of farmers $(n=400)$ reported that they washed and dried teats with a paper towel (Kelly et al., 2009b); therefore, increased emphasis on premilking teat preparation may be needed to further reduce TBC means.

Differences in monthly TBC between seasonal and split-calving herds were most apparent at the beginning and end of the year. Many split-calving herds have contracts to supply milk for the liquid milk market. Producers of liquid milk must meet stricter thresholds for TBC $(<30,000$ cells $/ \mathrm{mL})$ and this regulation may account for reduced TBC observed in bulk milk from split-calving herds at the beginning and end of the year. Additionally, the majority of split-calving herds were categorized as herd size 3 or 4 (data not shown) and larger herds had lower TBC, likely due to differences in facilities and management practices.

Annual means for LPC reported herein are greater than those reported elsewhere (Elmoslemany et al., 2009; Pantoja et al., 2009; Gillespie et al., 2012), suggesting that herds enrolled in this study were having difficulty maintaining low LPC counts. Four out of 5 annual mean LPC recorded were $>200 \mathrm{cfu} / \mathrm{mL}$, which is above the recommended threshold that requires action (Ruegg and Reinemann, 2002). Laboratory pasteurization count is usually associated with milking equipment hygiene and sanitation (Villar et al., 1996; Reinemann et al., 2003; Elmoslemany et al., 2009), and increased LPC often indicates a failure in the cleaning process. In dairy farms on Prince Edward Island (Elmoslemany et al., 2009), risk factors for increased LPC included low temperature of the cleaning solution, high waterhardness score, and high alkalinity of alkaline detergent wash. Regulations for equipment sanitation in the EU are brief (89/362/EEC) and only note that milking equipment must be cleaned, disinfected, and rinsed with potable water. There is no requirement for milking equipment to be washed with hot water. The absence of hot water in the parlor (Kelly et al., 2009b) and daily hot washes (O'Connell et al., 2013) could account for higher annual means than reported for countries where hot washes are a daily occurrence. Irish farmers should be encouraged to carry out daily hot washes with adequate detergent to overcome cleaning failures and ultimately lower LPC.

Annual LPC peaked in 2008, and greater monthly means were seen during the summer of 2008 compared with other years. Spore-forming thermoduric bacteria are ubiquitous in soil (Heyndrickx, 2011). As soil moisture increased and in the absence of teat preparation, Christiansson et al., (1999) found that the concentration of Bacillus cereus spores in bulk tank milk increased. The above-normal rainfall recorded during 2008 (Met 
Éireann, 2008) could have caused greater contamination of teats with thermoduric bacteria, which then contaminated the bulk tank milk.

In the current study, herds were tested for LPC twice a month. The lack of frequent testing may make it difficult for farmers to identify risk factors that influence LPC. Similar to trends reported by Gillespie et al. (2012), LPC was greatest in autumn and least in spring and winter. Despite current recommendations to change liners twice a year or every 2,000 milkings (Teagasc, 2008), Kelly et al. (2009b) reported that $64 \%$ of 400 farmers surveyed changed their liners once a year or less and found that this was associated with higher TBC. Declining condition of rubber teat cups and the build-up of milk residues in the milk line following continuous inadequate washes could account for the increase in LPC as lactation progresses.

Because cow numbers were unavailable to determine herd size, annual milk volume divided by the overall average milk production of Irish cows was used to establish herd-size categories. Although this form of classification did not account for underperforming large herds or overperforming small herds, the estimate closely approximated Irish census data for herd size (CSO, 2012). The estimate used in the current study resulted in $50 \%$ of farms being categorized as having $>55$ cows compared with census results showing that $55.48 \%$ of all farms contained $>50$ cows (CSO, 2012). Likewise, in the current study, the 25th percentile was similar to census data, whereby $25 \%$ of herds enrolled were estimated to have $<36$ cows compared with census results showing that $24 \%$ of all farms contained $<30$ cows. The 75 th percentile in this study was estimated to be 80 cows and although the census data do not give the exact breakdown, $38 \%$ of herds had between 50 and 100 cows and $11 \%$ of herds had $>100$ cows.

In agreement with research conducted in other regions (Oleggini et al., 2001; van Schaik et al., 2002; Ingham et al., 2011), larger herds had the lowest annual mean SCC and TBC. Capital investments in improved herd facilities often require a critical herd size to generate income for improvements (Bailey et al., 1997; Archer et al., 2013). Therefore, it is often more feasible for larger herds to improve herd infrastructure compared with smaller herds. More modern facilities could have an indirect effect on milk quality, and cows on larger herds may benefit from better facilities. Operators of larger herds in Wisconsin were more likely to have regular maintenance of the milking machine, adopt a complete milking routine, use recommended premilking teat preparation practices, and submit samples of bulk milk for microbiological culture compared with operators on smaller herds and, as a result, had a lower prevalence of subclinical mastitis (Rodrigues et al., 2005). Similarly, as herd size increased in Pennsylvania, management practices changed with respect to type of bedding used, sanitation wash (automatic, manual, or semiautomatic), dry cow treatment, forestripping, teat dipping, and towel type (Jayarao et al., 2004). In the current study, differences in SCC among herd sizes was most apparent from October to December, indicating greater prevalence of subclinical mastitis in late lactation on smaller herds. This difference in milk quality among herd sizes is most likely related to farming practices.

\section{CONCLUSIONS}

Annual bulk tank SCC increased slightly from 2007 to 2009 and then declined thereafter, whereas annual TBC remained stable and LPC increased from 2007 and 2011, peaking in 2008. Seasonal trends were observed for monthly SCC, with steady increases from October as the majority of cows entered late lactation, indicating increased prevalence of subclinical mastitis in late lactation. Efforts to reduce bulk tank SCC at this time of the year are warranted. Milk quality differed when herds were categorized based on their herd type and herd size. Seasonal herds had lower SCC from February to September, whereas split-calving herds had a lower SCC thereafter. The average DIM for each herd type differed depending on the month of the year and most likely accounted for the differences in bulk tank SCC. As average DIM increases, opportunities for cows to become exposed to mastitis pathogens increase. Successful education and implementation of well-recognized mastitis control programs on Irish farms could prevent the spread of contagious mastitis and reduce SCC in late lactation. Monthly TBC was greatest at the beginning and end of the year for both split-calving and seasonal herds. Suboptimal housing conditions combined with wetter weather conditions may account for increased TBC at these times. Split-calving herds had lower TBC at the beginning and end of the year than seasonal herds, likely because most split-calving herds have to meet stricter TBC regulations. Hygienic housing conditions and improved teat preparation have the potential to reduce TBC and overcome seasonal influences at the beginning and end of the year. Larger herds had lower SCC and TBC across all months compared with smaller herds. By monitoring milk quality trends in Ireland between 2007 and 2011, we concluded that considerable improvements in milk quality were not seen. Improvements in bulk tank SCC and TBC in late lactation and during winter are warranted. This could be achieved by improving hygiene in the cow's environment, thorough teat preparation, culling chronically infected cows, drying off low-yielding cows, and improving mastitis management. 


\section{ACKNOWLEDGMENTS}

Sincere gratitude is due to the processors who supplied the milk quality data. This work was supported by The Dairy Levy Research Trust (Dublin, Ireland). Aine O'Connell was in receipt of a Teagasc Walsh Fellowship.

\section{REFERENCES}

Archer, S. C., F. Mc Coy, W. Wapenaar, and M. J. Green. 2013. Association of season and herd size with somatic cell count for cows in Irish, English, and Welsh dairy herds. Vet. J. 196:515-521.

Bailey, K., D. Hardin, J. Spain, J. Garrett, J. Hoehne, R. Randle, R. Ricketts, B. Steevens, and J. Zulovich. 1997. An economic simulation study of large-scale dairy units in the Midwest. J. Dairy Sci. 80:205-214.

Barbano, D. M., Y. Ma, and M. V. Santos. 2006. Influence of raw milk quality on fluid milk shelf life. J. Dairy Sci. 89(E. Suppl.):E15-E19.

Barkema, H. W., Y. H. Schukken, T. J. Lam, M. L. Beiboer, H. Wilmink, G. Benedictus, and A. Brand. 1998. Incidence of clinical mastitis in dairy herds grouped in three categories by bulk milk somatic cell counts. J. Dairy Sci. 81:411-419.

Barkema, H. W., Y. H. Schukken, and R. N. Zadoks. 2006. Invited review: The role of cow, pathogen, and treatment regimen in the therapeutic success of bovine Staphylococcus aureus mastitis. J. Dairy Sci. 89:1877-1895.

Barrett, D., A. Healy, F. Leonard, and M. Doherty. 2005. Prevalence of pathogens causing subclinical mastitis in 15 dairy herds in the Republic of Ireland. Ir. Vet. J. 58:333-337.

Berry, D. P., B. O'Brien, E. J. O'Callaghan, K. O. Sullivan, and W. J. Meaney. 2006. Temporal trends in bulk tank somatic cell count and total bacterial count in Irish dairy herds during the past decade. J. Dairy Sci. 89:4083-4093.

Bertocchi, L., F. Fusi, and A. Scalvenzi. 2012. Preliminary observations on the relationship between animal welfare and somatic cell count of milk. Large Animal Review 18:259-263.

Chambers, J. V. 2002. The microbiology of raw milk. Pages 39-90 in Dairy Microbiology Handbook, 3rd ed. R. K. Robinson, ed. John Wiley \& Sons, Inc. Publication, New York, NY.

Champagne, C. P., R. R. Laing, D. Roy, A. A. Mafu, M. W. Griffiths, and C. White. 1994. Psychrotrophs in dairy products: their effects and their control. Crit. Rev. Food Sci. Nutr. 34:1-30.

Christiansson, A., J. Bertilsson, and B. Svensson. 1999. Bacillus cereus spores in raw milk: factors affecting the contamination of milk during the grazing period. J. Dairy Sci. 82:305-314.

Cook, N. B., T. B. Bennett, K. M. Emery, and K. V. Nordland. 2002. Monitoring nonlactating cow intramammary infection dynamics using DHI somatic cell count data. J. Dairy Sci. 85:1119-1126.

CSO. 2011. Intake of cow's milk by creameries and pasteurisers by domestic or import source, month and statistic. Accessed Nov. 21, 2013. http://www.cso.ie/px/pxeirestat/Statire/SelectVarVal/ Define.asp? maintable $=$ AKM01\&PLanguage $=0$

CSO. 2012. Census of agriculture 2010- final results. Accessed Oct. 9, 2014. http://www.cso.ie/en/media/csoie/releasespublications/ documents/agriculture/2010/full2010.pdf

CSO. 2014. Intake of cows milk by creameries and pasteurisers by domestic or import source, year and statistic. Accessed Dec. 26, 2014. http://www.cso.ie/px/pxeirestat/Statire/SelectVarVal/ saveselections.asp

DAFM. 2010a. Food Harvest 2020. A vision for Irish agri-food and fisheries. Accessed Jun. 21, 2013. http://www.agriculture.gov.ie/ media/migration/agri-foodindustry/foodharvest2020/2020FoodH arvestEng240810.pdf.

DAFM. 2010b. Annual review and outlook for agriculture, fisheries and food 2010/2011. Accessed Jul. 29, 2013. http://www.agriculture.gov.ie/publications/2011/ annualreviewandoutlookforagriculturefisheriesandfood20102011/ agriculturalcommoditiesinputs/milk/.
DAFM, 2011. Report on the establishment of a national conversion relationship between the BactoCount and BactoScan routine method results and anchor method results for enumerating total bacterial count in raw cow's milk. Dairy Science Laboratory, Backweston campus, Cellbridge, Kildare, Ireland.

DairyCo. 2014. Milk production - hygienic quality of milk. Accessed Jun. 24, 2014. http://www.dairyco.org.uk/resources-library/ market-information/supply-production/gb-hygienic-quality/.

DairyNZ. 2011. New Zealand dairy statistics 2010-11. Accessed Jun. 3, 2014. http://www.dairynz.co.nz/media/434167/new_zealand_ dairy_statistics_2010-11.pdf.

De Vliegher, S. 2013. Belgium milk quality report. Page 40 in Natl. Mastitis Counc. Annual Mtg. Proc., San Diego, Ca, Natl. Mastitis Counc., Inc., Verona, WI.

Dillon, P. 2011. The Irish dairy industry -Planning for 2020. Page 1-24 in Proc. Natl. Dairy Conf. 2011: The Irish Dairy Ind.: To 2015 and Beyond. Teagasc, Cork, Ireland.

Dillon, P., S. Crosse, G. Stakelm, and F. Flynn. 1995. The effect of calving date and stocking rate on the performance of spring-calving dairy cows. Grass Forage Sci. 50:286-299.

Elmoslemany, A. M., G. P. Keefe, I. R. Dohoo, and B. M. Jayarao. 2009. Risk factors for bacteriological quality of bulk tank milk in Prince Edward Island dairy herds. Part 2: Bacteria count-specific risk factors. J. Dairy Sci. 92:2644-2652.

Elmoslemany, A. M., G. P. Keefe, I. R. Dohoo, J. J. Wichtel, H. Stryhn, and R. T. Dingwell. 2010. The association between bulk tank milk analysis for raw milk quality and on-herd management practices. Prev. Vet. Med. 95:32-40.

EEC (European Economic Community). 1992. Council Directive 92/46/EEC. Commission Document 39L0046. June 1992. EEC, Brussels, Belgium.

Fenlon, D. R., D. N. Logue, J. Gunn, and J. Wilson. 1995. A study of mastitis bacteria and herd management practices to identify their relationship to high somatic cell counts in bulk tank milk. Br. Vet. J. 151:17-25.

Geary, U., N. Lopez-Villalobos, N. Begley, F. McCoy, B. O'Brien, L. O'Grady, and L. Shalloo. 2012. Estimating the effect of mastitis on the profitability of Irish dairy herds. J. Dairy Sci. 95:3662-3673.

Gillespie, B. E., M. J. Lewis, S. Boonyayatra, M. L. Maxwell, A. Saxton, S. P. Oliver, and R. A. Almeida. 2012. Short communication: Evaluation of bulk tank milk microbiological quality of nine dairy herds in Tennessee. J. Dairy Sci. 95:4275-4279.

Hagnestam-Nielsen, C., U. Emanuelson, B. Berglund, and E. Strandberg. 2009. Relationship between somatic cell count and milk yield in different stages of lactation. J. Dairy Sci. 92:3124-3133.

Halasa, T., M. Nielen, A. P. W. De Roos, R. Van Hoorne, G. de Jong, T. J. G. M. Lam, T. van Werven, and H. Hogeveen. 2009. Production loss due to new subclinical mastitis in Dutch dairy cows estimated with a test-day model. J. Dairy Sci. 92:599-606.

Hayes, M. C., R. D. Ralyea, S. C. Murphy, N. R. Carey, J. M. Scarlett, and K. J. Boor. 2001. Identification and characterization of elevated microbial counts in bulk tank raw milk. J. Dairy Sci. 84:292-298.

Heyndrickx, M. 2011. The importance of endospore-forming bacteria originating from soil for contamination of industrial food processing. Appl. Environ. Soil Sci. 2011:561975. http://dx.doi. org/10.1155/2011/561975

Huijps, K., H. Hogeveen, G. Antonides, N. I. Valeeva, T. J. G. M. Lam, and A. G. J. M. O. Lansink. 2010. Sub-optimal economic behavior with respect to mastitis management. Eur. Rev. Agric. Econ. 37:553-568.

ICAR. 2009. National milk production. Accessed Jun. 24, 2014. http:// www.survey-icar.org/cow_survey/Ireland/IRE_index.htm.

ICBF. 2009. ICBF 2009 Annual report. Accessed Jul 4, 2014. http:// www.icbf.com/publications/files/Annual_Report_for_2009.pdf.

ICBF. 2011. ICBF 2011 Annual report. Accessed Jun. 24, 2013. http:// www.icbf.com/publications/files/Annual_Report_2011v2.pdf.

IDF. 2012. The world dairy situation 2012. Accessed Jun. 21, 2013 http://dms/sites/Research/MPA/Moorepark\%20Library\%20 Documents/IDF\%20Bulletins / Bull\%20IDF\%20458\%20\%20 2012\%20The\%20World\%20Dairy\%20Situation\%202012.pdf. 
IFCN. 2009. Overview on milk prices and production costs worldwide. Accessed Jul. 4, 2014. http://www.ifcndairy.org/media/ downloads/Press-release-IFCN-Dairy-Report-2013.pdf.

Ingham, S. C., Y. Hu, and C. Ane. 2011. Comparison of bulk-tank standard plate count and somatic cell count for Wisconsin dairy herds in three size categories. J. Dairy Sci. 94:4237-4241.

Jayarao, B. M., S. R. Pillai, A. A. Sawant, D. R. Wolfgang, and N. V. Hegde. 2004. Guidelines for monitoring bulk tank milk somatic cell and bacterial counts. J. Dairy Sci. 87:3561-3573.

Jayarao, B. M., and D. R. Wolfgang. 2003. Bulk-tank milk analysis. A useful tool for improving milk quality and herd udder health. Vet. Clin. North Am. Food Anim. Pract. 19:75-92.

Jimenez, L. M. 2013. Spain Milk Quality Report. Page 38 in Natl Mastitis Counc. Annual Mtg. Proc., San Diego, CA. Natl. Mastitis Counc. Inc., Verona, WI.

Keane, O. M., K. E. Budd, J. Flynn, and F. McCoy. 2013. Pathogen profile of clinical mastitis in Irish milk-recording herds reveals a complex aetiology. Vet. Rec. 173:17.

Kelly, P. T., K. O’Sullivan, D. P. Berry, S. J. More, W. J. Meaney, E. J. O'Callaghan, and B. O'Brien. 2009a. Herd management factors associated with bulk tank somatic cell count in Irish dairy herds. Ir. Vet. J. 62:45-51.

Kelly, P. T., K. O'Sullivan, D. P. Berry, S. J. More, W. J. Meaney, E. J. O'Callaghan, and B. O'Brien. 2009b. Herd management factors associated with bulk tank total bacterial count in Irish dairy herds during 2006/07. Ir. Vet. J. 62:36-42.

Met Éireann. 2008. Climatological note no. 112008 summer rainfall in Ireland. Accessed Jun. 24, 2014. http://www.met.ie/climate/ monthlyBulletins/Summer2008rainfall.pdf.

Met Éireann. 2010. Weather 2010. Accessed Jun. 24, 2014. http:// www.met.ie/climate/monthly_summarys/year10sum.pdf.

More, S. J. 2009. Global trends in milk quality: Implications for the Irish dairy industry. Ir. Vet. J. 62:S5-14.

National Milk Agency. 2010. Annual report and accounts 2010. Accessed Jun. 24, 2013. http://www.nationalmilkagency.ie/pdfs/ nma_ar10_en.pdf.

Neave, F. K., F. H. Dodd, R. G. Kingwill, and D. R. Westgarth. 1969. Control of mastitis in dairy herds by hygiene and management. J. Dairy Sci. 52:696-707.

NMC. 2012. Somatic cell count in DHI herds averaged 200,000 in 2012. Accessed May 26, 2014. http://www.nmconline.org/articles/ scc2012.html.

O'Connell, A., P. L. Ruegg, and D. Gleeson. 2013. Farm management factors associated with the Bacillus cereus count in bulk tank milk. Ir. J. Agric. Food Res. 52:229-241.

Oleggini, G. H., L. O. Ely, and J. W. Smith. 2001. Effect of region and herd size on dairy herd performance parameters. J. Dairy Sci. 84:1044-1050

Pantoja, J. C. F., D. J. Reinemann, and P. L. Ruegg. 2009. Associations among milk quality indicators in raw bulk milk. J. Dairy Sci. 92:4978-4987.
Reinemann, D. J., G. Wolters, P. Billon, O. Lind, and M. D. Rasmussen. 2003. Review of practices for cleaning and sanitation of milking machines. Bull. Int. Dairy Fed. 381:3-18.

Rhoda, D. A., and J. C. F. Pantoja. 2012. Using mastitis records and somatic cell count data. Vet. Clin. North Am. Food Animal Pract. $28: 347-362$.

Rodrigues, A. C. O., D. Z. Caraviello, and P. L. Ruegg. 2005. Management of Wisconsin dairy herds enrolled in milk quality teams. J. Dairy Sci. 88:2660-2671.

Ruegg, P. L. 2003. Practical food safety interventions for dairy production. J. Dairy Sci. 86(E-Suppl.):E1-E9.

Ruegg, P. L., and J. C. F. Pantoja. 2013. Understanding and using somatic cell counts to improve milk quality. Ir. J. Agric. Food Res. 52:101-117.

Ruegg, P. L., and D. J. Reinemann. 2002. Milk quality and mastitis tests. Bovine Pract. 36:41-54.

Ruegg, P. L., and T. J. Tabone. 2000. The relationship between antibiotic residue violations and somatic cell counts in Wisconsin dairy herds. J. Dairy Sci. 83:2805-2809.

SAS Institute. 2011. SAS 9.3 Output Delivery System: User's Guide. SAS Institute Inc., Cary, NC.

Schepers, A. J., T. J. G. M. Lam, Y. H. Schukken, J. B. M. Wilmink, and W. J. A. Hanekamp. 1997. Estimation of variance components for somatic cell counts to determine thresholds for uninfected quarters. J. Dairy Sci. 80:1833-1840.

Schukken, Y. H., D. J. Wilson, F. Welcome, L. Garrison-Tikofsky, and R. N. Gonzalez. 2003. Monitoring udder health and milk quality using somatic cell counts. Vet. Res. 34:579-596.

Teagasc. 2008. Milk quality handbook: Practical steps to improve milk quality. Accessed Jan. 1, 2015. http://www.teagasc.ie/ publications/2008/1486/5520-MPK-Dairy-Levy-Update_Series8. pdf.

Thompson, D. I., C. B. Donnelly, and L. A. Black. 1960. A plate loop method for determining viable counts of raw milk. J. Milk Food Technol. 23:167-171.

van Schaik, G., M. Lotem, and Y. H. Schukken. 2002. Trends in somatic cell counts, bacterial counts, and antibiotic residue violations in New York State during 1999-2000. J. Dairy Sci. 85:782-789.

Villar, A., J. A. Garcia, L. Iglesias, M. L. Garcia, and A. Otero. 1996. Application of principal component analysis to the study of microbial populations in refrigerated raw milk from herds. Int. Dairy J. 6:937-945

Wilson, D. J., H. H. Das, R. N. Gonzalez, and P. M. Sears. 1997. Association between management practices, dairy herd characteristics, and somatic cell count of bulk tank milk. J. Am. Vet. Med. Assoc. 210:1499-1502

Zadoks, R. N., B. E. Gillespie, H. W. Barkema, O. C. Sampimon, S. P. Oliver, and Y. H. Schukken. 2003. Clinical, epidemiological and molecular characteristics of Streptococcus uberis infections in dairy herds. Epidemiol. Infect. 130:335-349. 